\title{
Experimental Study of Primary Compression Settlement of Bioreactor Landfills
}

\author{
Sun Hong-jun ${ }^{*}$, Cao Bin and Zhao Li-hong \\ College of Civil Engineering, Liaoning University of Technology, Liaoning Jinzhou 121001, China
}

\begin{abstract}
A set of primary compression settlement apparatus was designed in order to evaluate the compression characteristic of bioreactor landfill and forecasting primary compression settlement of garbage body under load. The primary compression settlement test of landfill was conducted by this apparatus in laboratory. Three groups of parallel tests were carried out. When daily average settlement is less than $0.1 \mathrm{~cm}$, the test is over. At the end of the test, the primary compression settlement reached $68 \%, 63 \%$ and $60 \%$ of a total settlement respectively. Test showed that domestic garbage is a highly compressibility material. There exists the direct relation between primary compression settlement and initial dry density. Simultaneously, the compression settlement rate decreases with load increasing.
\end{abstract}

Keywords: Bioreactor landfill, Compression settlement rate, Initial dry density, Primary compression settlement.

\section{INTRODUCTION}

Bioreactor landfill with leachate recirculation can accelerate the degradation velocity of organic matter in landfill, which has gradually been paid great attention in the researchers $[1,2]$. In order to evaluate the compression characteristics of MSW and predict the main compression settlement of garbage body under load, by compressibility test of household garbage, using stress-strain curve relationship of landfill primary compression settlement and analysis settlement mechanism of garbage body main compression, at the same time shows that household garbage has high compressibility and there is a direct relationship between the main compression settlement and initial dry density $[3,4]$.

\section{THE DEVELOPMENT OF TEST EQUIPMENT}

A set of primary compression settlement apparatus was designed for the primary compression settlement test of landfill was conducted by this apparatus in laboratory (Fig. 1). The instrument main body is a transparent organic glass barrel which barrel wall thickness is $12 \mathrm{~mm}$. The barrel is divided into three parts, where in the bottom barrel ceiling height is $500 \mathrm{~mm}$ and the barrel wall thickness is $18 \mathrm{~mm}$, the high of upper two barrels are respectively $600 \mathrm{~mm}$ and $1100 \mathrm{~mm}$. According to the need you can combine with different barrel for $1100 \mathrm{~mm}$ and $1700 \mathrm{~mm}$ garbage primary compression settlement test [5]. Each barrel are reinforced by the steel hoop, which ensure safety and sealing during the trial.

Inner diameter of the equipment body tube is $300 \mathrm{~mm}$, the bottom is provided with a leachate efflux switch, opening at the top. In order to ensure the stable effect of load maximum lateral pressure on the bottom, equipment pipe wall thickness at the bottom of equipment is $18 \mathrm{~mm}$ larger than the upper tube wall thickness. At the same time, laying of a circular bottom plate at the bottom of equipment, which thickness is $20 \mathrm{~mm}$. The edge of circumferential are drilled with a small hole, and base is connected with tube wall body by the bolt, between the connecting pieces is sealed with a rubber gasket.

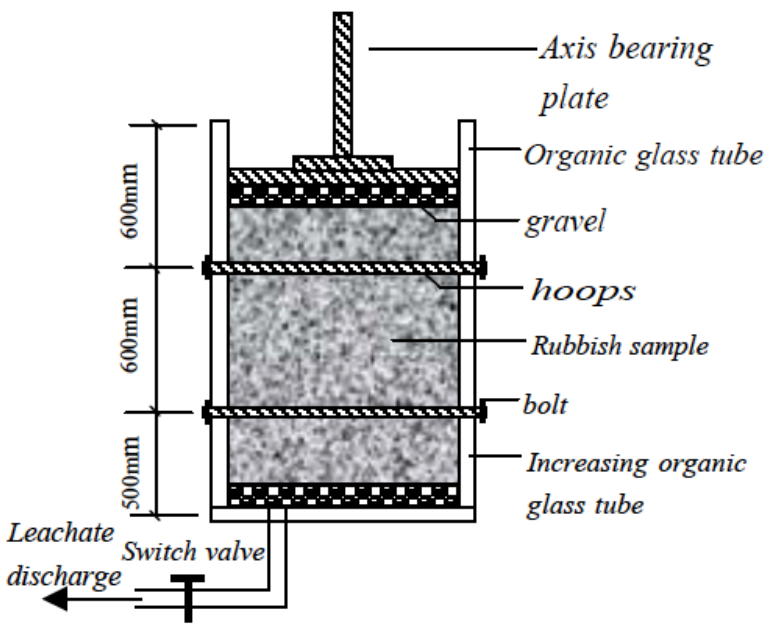

Fig. (1). Primary compression settlement apparatus.

Equipment loading device is weight loading method, in order to ensure the vertical axial compression of waste sample and not produce lateral pressure, a thick $5 \mathrm{~mm}$ weight tray are installed on the upper part of equipment, a axis vertical rod $15 \mathrm{~mm}$ in diameter is welded in the central of tray, composed of vertical bearing plate in the test. At the same time circumferential edge of the tray is provided with a circular hole, which ensures gas from the landfill samples can dissipate. Loading weight, prefabricated cast iron disc, are respectively provided with $0.35 \times 10^{3} \mathrm{~N}, 0.7 \times 10^{3} \mathrm{~N}, 1.4 \times 10^{3} \mathrm{~N}$, $1.75 \times 10^{3} \mathrm{~N}, 3.5 \times 10^{3} \mathrm{~N}, 7 \times 10^{3} \mathrm{~N}, 10.5 \times 10^{3} \mathrm{~N}, 24.5 \times 10^{3} \mathrm{~N}$, $28 \times 10^{3} \mathrm{~N}$ nine levels. 


\section{TEST PLAN AND TEST PROCESS TEST PLAN}

The experiment was divided into 3 groups of parallel tests carried out at the same time. The same percentage of sample quality each test, test process and the loading scheme is the same, but initial dry density is different, which were labeled as experiment 1 , experiment 2 and experiment 3 .

According to the proportion, materials samples of the test are from a garbage field, at the same time referencing soil test method requirements on particle diameter, on each component test size are strictly controlled. To make sure the waste sample can be evenly distributed by using of different means and methods, materials are mixed and evenly stirred then certain water content must be controlled; In order to avoid effect that the degradation of organic matter in living garbage for the main settlement compression test, there must be adding a certain amount of $\mathrm{K}_{2} \mathrm{CO}_{3}$ and $\mathrm{Na}_{2} \mathrm{CO}_{3}$ in waste sample [4]; The mixed waste sample layered into main compression settlement apparatus. Before putting the garbage samples into, the inner wall of compression apparatus must be treated with Vaseline, which reduced friction between the garbage sample and the organic glass bucket. The bottom of the device is paved with diameter less than $5 \mathrm{~mm}$ gravel and waste sample divided into six layers of landfill components in the test. The thickness of each layer was $200 \mathrm{~mm}$, separating the layers with geotextile, to mark the vertical settlement measurement at the same time (Table 1).

Table 1. Composition of waste samples of primary compression settlement test.

\begin{tabular}{|c|c|c|c|c|}
\hline & $\begin{array}{c}\text { Quality } \\
\text { \% }\end{array}$ & $\begin{array}{c}\text { Test1 } \\
(\mathbf{k g})\end{array}$ & $\begin{array}{c}\text { Test 2 } \\
(\mathbf{k g})\end{array}$ & $\begin{array}{c}\text { Test 3 } \\
(\mathbf{k g})\end{array}$ \\
\hline \hline Kitchen waste & 40.5 & 5.96 & 6.24 & 6.58 \\
\hline paper & 4.2 & 0.44 & 0.65 & 0.68 \\
\hline Bamboo and wood & 3.1 & 0.44 & 0.48 & 0.51 \\
\hline fiber & 4.7 & 0.7 & 0.72 & 0.76 \\
\hline plastic & 3.4 & 0.51 & 0.52 & 0.55 \\
\hline metal & 1.7 & 0.2 & 0.26 & 0.28 \\
\hline Ceramic glass & 5.9 & 0.9 & 0.97 & 0.96 \\
\hline Coal ash & 36.5 & 5.5 & 5.56 & 5.93 \\
\hline
\end{tabular}

The main compression tests considered to avoid influence as far as possible in the test the degradation of trash organic matters for primary compression settlement. In order to make the results primary compression settlement more accurate there was not only putting the chemical reagent into the test, but also limiting the indoor temperature, permeability, $\mathrm{pH}$ value.

Before start of the experiment, firstly according to the test requirements, test equipment must be assembled and leveled and measurement equipment must be calibrated, pending trial. Before putting Waste sample into compression instrument, in compression instrument bottom laid a layer of less than $5 \mathrm{~mm}$ in diameter gravel, between gravel and waste sample with geomembrane, from the bottom to up, waste sample were placed in 6 layers, each $20 \mathrm{~cm}$ for the layer, each layer of laying geotextiles of good permeability, and to mark, which it is convenient to record settlement data. Specimen top also laid of a layer of gravel $5 \mathrm{~cm}$ in diameter, reading each floor height and total height of the specimen before loading. Landfill's total quality respectively: mass of Test 1 was $14.65 \mathrm{Kg}$, mass of test 2 was $15.40 \mathrm{~kg}$ and mass of test 3 was $16.25 \mathrm{~kg}$; loading levels respective was $5 \mathrm{KPa}$, $10 \mathrm{KPa}, 20 \mathrm{KPa}, 25 \mathrm{KPa}, 50 \mathrm{KPa}, 100 \mathrm{KPa}, 150 \mathrm{KPa}, 350$ $\mathrm{KPa}$ and $400 \mathrm{KPa}$. Under the pressure, stability criteria for each level were consolidation for $24 \mathrm{~h}$.

\section{TEST RESULTS OF PRIMARY COMPRESSION SETTLEMENT}

The main compression test data is observed which lasted 37 days; it is found that the settlement is very slow after recording waste sample's total settlement. Average subsidence quantity of the test in 1 day is $0.13 \mathrm{~mm}$. Average subsidence quantity of the test in 2 day is $0.26 \mathrm{~mm}$. Average subsidence quantity of the test in 3 day is $0.10 \mathrm{~mm}$; it may be considered the primary compression settlement has been basically completed [6].

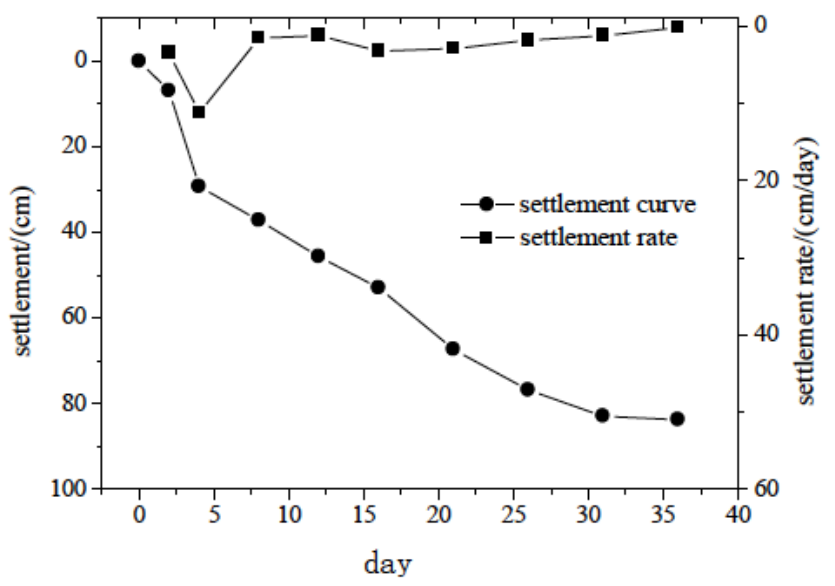

Fig. (2). The curves of primary compression settlement of test 1 .

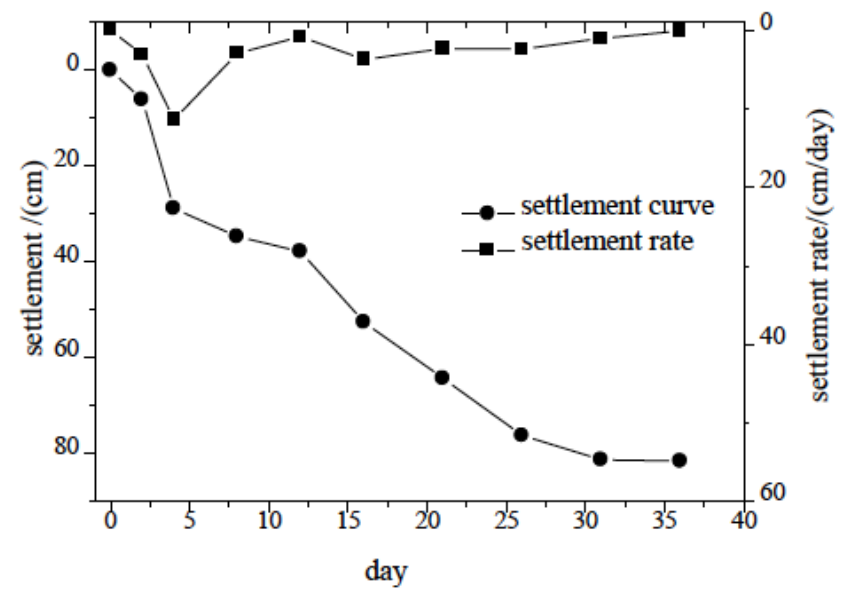

Fig. (3). The curves of primary compression settlement of test 2. 


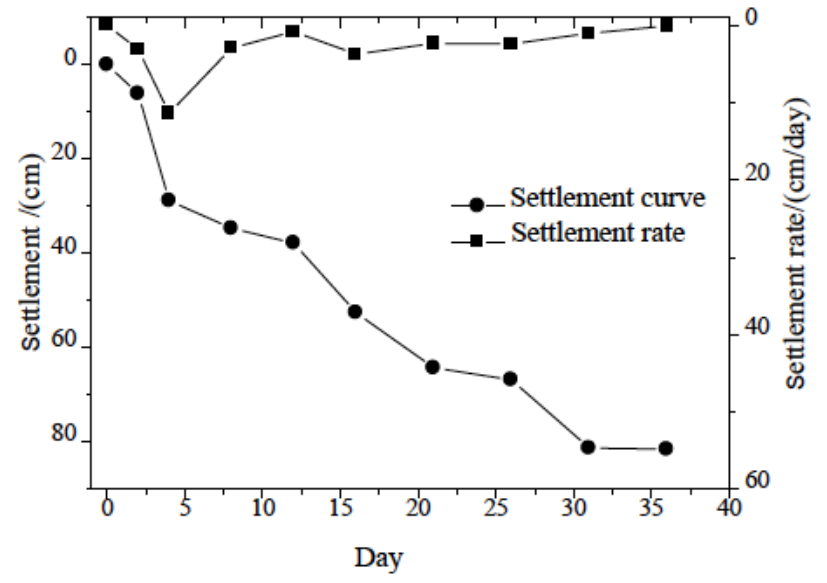

Fig. (4). The curves of primary compression settlement of test 3 .

Load level in the three experimental groups were $5 \mathrm{KPa}$, $10 \mathrm{KPa}, 20 \mathrm{KPa}, 25 \mathrm{KPa}, 50 \mathrm{KPa}, 100 \mathrm{KPa}, 150 \mathrm{KPa}, 350$ $\mathrm{Kpa}$ and $400 \mathrm{KPa}$, load interval is $24 \mathrm{~h}$,where the compression time of $350 \mathrm{KPa}$ is $36 \mathrm{~h}$, long-term constant load compression test after $400 \mathrm{KPa}$, compression time is a total of 37 days $[5,6]$. Three groups of test results is shown in (Figs. 24), respectively, said experiment 1 experiment 2 and experiment 3 that main compression curve changes with the load settlement. Primary compression settlement changes a lot with load from 0 to $50 \mathrm{KPa}$, in the three experimental groups primary compression settlement respectively reach total settlement of $68 \%, 63 \%$ and $60 \%$, which indicates that the life garbage is highly compressible material. The early stage of the compression quantity is big, at the same time because of the different initial dry density of three groups of experiments, the main compression settlement also exist differences, which shows that there is a direct relationship between the main compression the initial dry density. As the load increases, the compression settling rate decreases. From the figure it clearly can be seen main waste compression subsidence and sedimentation rate along with the change of time curve, with the increase of load, compression rate decreases gradually. Under the action of load, starting loading within the $5 \mathrm{~h}$, the compression rate is bigger. The biggest change within $1 \mathrm{~h}$, compression rate gradually flatten out after $5 \mathrm{~h}[7,8]$.

\section{ANALYSIS OF EXPERIMENTAL RESULTS OF PRIMARY COMPRESSION SETTLEMENT}

From the results of main compression test, prolong the main living garbage compression gradually increased with time, especially in the initial stage of compression. Based on the primary compression settlement observation tests, compression of $24 \mathrm{~h}$ of the total amount of compression ratio is generally above $85 \%$, then gradually decreased, and the proportion is relative to the size of initial dry density of waste and the size of the pressure. When Initial dry density of garbage is small, the initial primary compression settlement amount is large, because of garbage with small initial dry density, each component size is generally big, the contact surface they contact each other is not big, there may be a point contact, the meshing between various components is not quite close together,, surround close space between each component is not filled with tiny particles or small size of the garbage, unable to bear external pressure. Living garbage under the load function, garbage's of contact among the components is gradually destroyed, space between components gradually was compressed and point contact became the surface contact, the porosity between garbage decreases. Due to the inherent characteristics of this kind of itself of garbage, which resulted in compression of its initial was big. With the gradual compacting of garbage, the contact area of each component increased and waste dry density also increased, the new reestablished contact surface can bear larger pressure, therefore, and then garbage main compression was more and more smaller (Figs. 5-7).

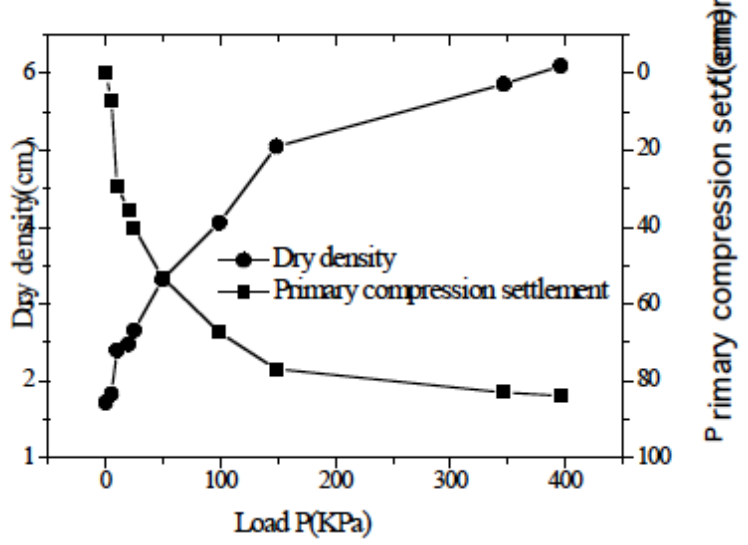

Fig. (5). The curves of primary compression and dry density of test 1.
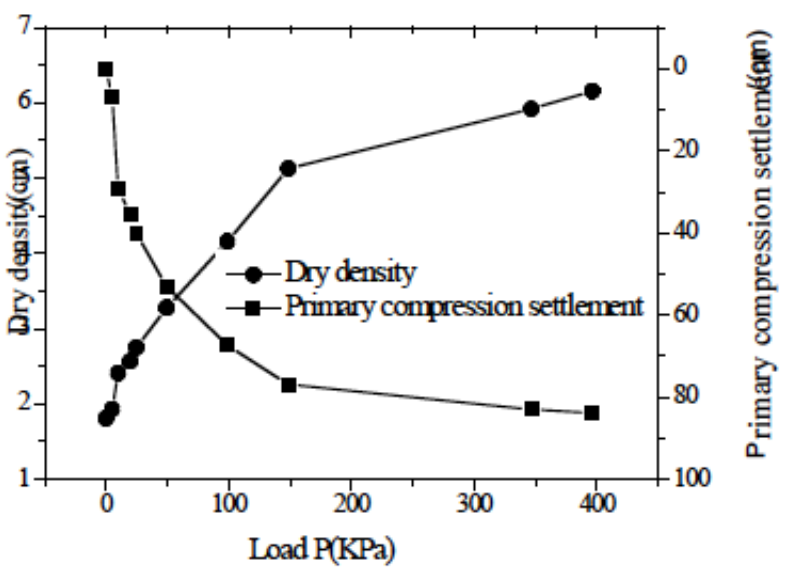

Fig. (6). The curves of primary compression and dry density of test 2.

Living garbage primary compression settlement in fact depends on the size of the garbage composition, the proportion of the amount of each relationship, water content, drainage condition, the size of the pressure, etc. $[9,10]$. Garbage itself three composition is composed of solid, liquid and gas, the solid phase of soil is different from general engineering, the solid particles in general engineering soil is granular or flaky, soil and waste solid part not only has solid phase of general engineering, but also has organic matter, the mechanical properties of organic and are different from inorganic. In the process of primary compression settlement test, because the waste sample mixed $\mathrm{K}_{2} \mathrm{CO}_{3}$ and $\mathrm{Na}_{2} \mathrm{CO}_{3}$ to 
prevent the degradation of organic matter in waste material, so that you could slow the secondary compression settlement of garbage. When using this test method, organic in garbage sample will have no enough time to degrade and the mass loss rate is about $1.02 \%$, so it can be considered that the test methods in largely eliminated influence the degradation of organic matter on the test result. Hossain M.S. et al. also studied the primary compression settlement regularity of garbage by using the method [8]. So this paper studying the main garbage compression settlement is under the condition of no account of organic matter degradation of primary compression settlement rule.

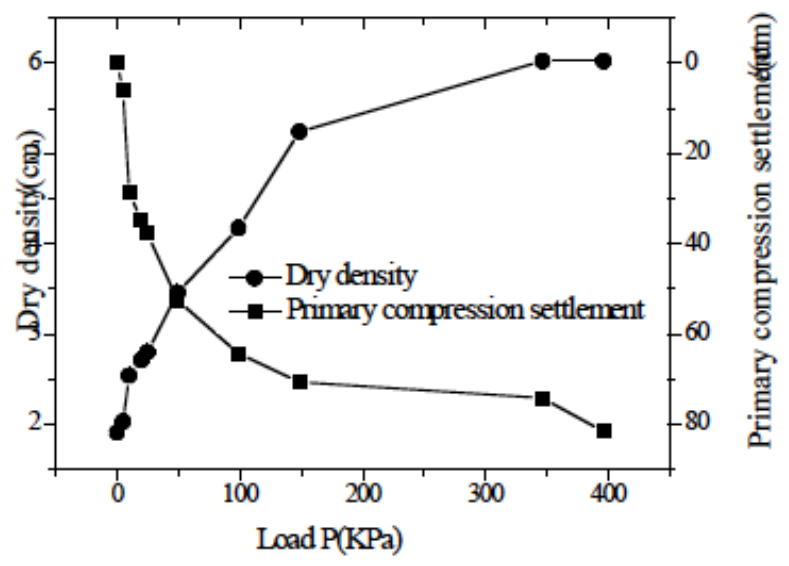

Fig. (7). The curves of primary compression and dry density of test 3 .

\section{CONCLUSION}

A set of primary compression settlement apparatus was designed in order to study the indoor experiment of bioreactor landfill owner compression on the subsidence.

The experiment was divided into 3 groups of parallel tests carried out at the same time, with the same percentage of specimen quality each test, but different initial dry density.

In the three experimental groups' primary compression settlement respectively reach total settlement of $68 \%, 63 \%$ and $60 \%$. Under the action of load, starting loading within the $5 \mathrm{~h}$, the compression rate is bigger. The biggest change within $1 \mathrm{~h}$, compression rate gradually flatten out after $5 \mathrm{~h}$.

The test indicates that the life garbage is highly compressible material. And there is a direct relationship between the main compression the initial dry density. As the load increases, the compression settling rate decreases.

This paper studying the main garbage compression settlement is under the condition of no account of organic matter degradation of primary compression settlement rule.

\section{CONFLICT OF INTEREST}

The authors confirm that this article content has no conflict of interest.

\section{ACKNOWLEDGEMENTS}

Much of the work described in this paper was supported by Dr. Start-up Foundation projects of liaoning province in China under Grant Nos. 20131046, The writers would like to greatly acknowledge all these financial supports and express the most sincere gratitude.

\section{REFERENCES}

[1] M. El-Fadel, and R. Khoury, "Modeling Settlement in Msw Landfills," A Critical Review. Critical Review of Environmental Science and Technology, vol. 30, pp. 327-365, 2010.

[2] F. Olivier, and J. P. Gourc, "Hydro-mechanical behavior of Municipal Solid Waste subject to leachate recirculation in a large-scale compression reactor cell," Waste Managemen, vol. 27, pp. 44-58, 2007.

[3] C. H. Hettiarachchi, J.N.Meegoda, and J.P.A.Hettiaratchi, "Settlement of Bioreactor Landfills," Modelling of Settlement Behavior of Bioreactor Landfills. Alberta, Canada, Department of Civil Engineering, University of Calga, 2009.

[4] X. Kong, X. Sun, and D. Zou, "Creep-Degradation Properties of Municipal Solid Waste in Laboratory Tests," Rock and Soil Mechanics, vol. 2, pp. 337-341, 2008.

[5] Y. Liu, and C. Huang, "Estimation of Long-Term Settlement of Landfill Considering Biological Decomposition," Rock and Soil Mechanics, vol. 9, pp. 1532-1534, 2006.

[6] Y. Xie, Y. Chen, and X. Tang, "Mathematical Model for Landfill Settlement Considering Gas-Solid Coupling Effect," Chinese Journal of Rock Mechanics and Engineering, vol. 25, pp. 601-608, 2010.

[7] G.L. Sivakumar, R. Babu, and K. Reddy, "Chouksey. Constitutive model for municipal solid waste incorporating mechanical creep and biodegradation-induced compression," Waste Management, 2009.

[8] J. McDougall, "A Hydro-Bio-Mechanical Model for Settlement and Other Behaviour in Landfilled Waste," Computers and Geotechnics, vol. 34, pp. 229-246, 2007.

[9] D. Wang, D. Liu, and Q. Liu, "Research on the Variation Regularity of Effluent from the Leachate Reverse Osmosis Concentrate Recirculation," Environmental Science, vol. 35, pp. 2822-2828, 2014.

[10] G. L. Zhang, L. Qin, and Q. Meng, “Aerobic SMBR/reverse osmosis system enhanced by Fenton oxidation for advanced treatment of old municipal landfill leachate," Bioresource Technology, vol. 142, pp. 261-268, 2013. 